\title{
The Serpent God Nhb-Kaw
}

\author{
By
}

\section{DR/Mariana Abd Elsayed Asham}

\begin{abstract}
The serpent god Nhb-Kaw whose name means "He-who Harnessesthe Spirits", was first attested in the Pyramid Texts and was regarded as a benign and helpful deity. He assisted the deceased king in various ways and seems to act as an intercessory on his behalf.The god was believed to be the son of the scorpion goddess Serket, though an alternative tradition claimed that he was the son of earth god Geb and the serpent Harvest goddess Renenutet. His chthonic origins and serpentine nature-coupled with "seven cobras" he is said to have swallowed- are the source of Nhb-Kaw's considerable power. This is seen in later texts which assert that Nhbu-Kaw is not subject to any harmful magic and cannot be harmed by water or fire. The god's consort was thought to be Nehemtawy ${ }^{(1)}$.

He was at one point a rather fierce and aggressive deity, and so the god Atum had to press his nail into Nhb-Kaw's spine, so he could control the serpent god. The ancient Egyptians believed that he could not be overcome with magic, fire or water ${ }^{(2)}$.

\section{Methodology}

This paper aims to a descriptive and analytical study of the benevolent serpent god who are the Egyptians believed was one of the original primeval gods. The origin of his name according to different texts; the iconography; his cult and relation between him and other gods and how he was linked to the sun god, swimming around in the primeval waters before creation, then bound to the sun god when time began.
\end{abstract}

\section{Keywords}

Nhb-Kaw, Serpent deity, Deity of Protection and Magic.

His Name

His name comes from the ancient Egyptian word for 'yoke together' or 'unite'. His name implies that he is the one that brings together the Ka-of a person, an animal, a plant, a body of water or even a stone and unites them with the physical body of a person, an animal, a plant, a body of water or

${ }^{1}{ }^{1}$ Ch. Leitz, Lexikon der Ägyptischen Götter und Götterbezeichnungen VI (Germany, 2002), 283; R.H. Wilkinson, The Complete Gods and Goddesses of Ancient Egypt (Cairo, 2003), 224..

$\left({ }^{2}\right)$ A.W. Shorter, The God Nḥb-K3 w, Journal of Egyptian Archeaology 21 (Cairo, 1935), 41-48. 
even a stone and unites the double with the physical body that the ka would reside in, whether a spirit or an object.

The name of Nhb-kaw, means 'who Enumerate theSouls; ${ }^{(3)}$ 'One who bestows glory to the souls ${ }^{(4)}$. The epithet of Nhbw-kaw is mentioned as it means the "Bestower of Dignities" "He who appoints the positions, ${ }^{(5)}$ of the gods and the dead, which gives it another meaning, like "the Over turnerof Doubles" ${ }^{(6)}$.

While according to Leitz ${ }^{(7)}$ his name means "the One who grants the ka". Piankoff ${ }^{(8)}$ points that, it means "the One who collects the Souls" or "Who grants the food or welfare" ${ }^{(9)}$ (Fig.1): "Teti is summoned by Ra, food is given to him by Nhb-Kaw as to Horus, as to the horizon-dweller"(10).

The first section Nhb means tie; attack; and defend, so, the name was explained sometimes as "the One who conquers the ka"(11), may it refers to his power over the souls ${ }^{(12)}$.

\section{Iconography}

Although Nhb-kaw is called a 'great serpent, multitudinous of coils' in the Pyramid Texts and may be depicted in this manner, he was frequently

$\left({ }^{3}\right)$ L. Speleers, Les Textes des Pyramides Égyptiennes, Revue des Études Anciennes 2, (Paris, 1924), 54-58; B. Altenmüller, Synkretismus in den Sargtexten (German, 1975), 96.

$\left.{ }^{4}\right) \mathrm{K}$. Sethe, Dramatische Texte zu Altaegyptischen Mysterienspielen, Untersuchungenzur Geschichte und Altertumsk und Ägyptens 10 (Hildesheim, 1964), 63.

${ }^{5}$ )A.W., Shorter, The God Nḥb-Kaw, Journal of Egyptian Archeaology 21 (Cairo, 1935) 41-48.

$\left.{ }^{6}\right)$ M.W. Müller, The Mythology of all Races. Egyptian (Boston, 1918), 141. ${ }^{7}$ )Ch.Leitz, Lexikon VI, 273; W. Barta, Nehebkaw, Lexikon der Ägyptologie VI (Wiesbaden, 2002), 388-390.

$\left({ }^{8}\right)$ A. Piankoff \& E. Drioton, The Tomb of Ramesses VI (New York, 1954), 668.

$\left({ }^{9}\right)$ E.G. Daressy, Statues Des Divinities, (Cat, Gen, du Musee du Caire, l'Institut Français d'Archéologie Orientale (La Caire, 1905-1906), No.38837, 38842.

$\left({ }^{10}\right) \mathrm{K}$. Sethe, Die Altaegyptische Pyramiden texte: nach den Papier abdrücken und Photographien des Berliner Museums, (Leipzig,1922), p.346a.

$\left({ }^{11}\right)$ L. Speleers, Les Textes des Pyramides Égyptiennes, Revue des Études Anciennes, Vol.2 (Bruxelles, 1924), 54-58.

$\left({ }^{12}\right) \mathrm{K}$. Sethe, Die Altaegyptische, $1146 \mathrm{~b}$. 
represented as a man with a serpent's head and tail. In serpent form, he is sometimes depicted on the sides of divine thrones, doubtless as a protective deity with a semi-anthropomorphic form. He is often depicted on amulets andplaques with his arm raised before him holding an offering pot ${ }^{(13)}$.

\section{The god appears in the following forms}

1) Nhb-kaw appears as a god who is said to possess" numerous coils" ${ }^{(14)}$ and called hf3w who in a pictorial form of the Fourth Division of the Amduat' the Kingdom of Sokar'(Fig.2),in the form of a huge serpent with two heads on separate necks, and its tail ends with a head ${ }^{(15)}$.The latter head is grasped by a god in human form called ${ }^{3} b-d^{3} t$, who holds a curious staff with curled end in his other hand. The text reads as: 'He is in the Fashion at his abode ofthe water flood, the holy road of Rostau ${ }^{(16)}$. He goes to every place every day, and he lives upon the excess of his utterance ${ }^{(17)}$. He is depicted also as a serpent of indefinite species or as a serpent headed-man (Fig.3), or as a serpent with human arms and legs, occasionally with wings (Fig.4). Sometimes the serpent form of Nhb-Kaw is shown with two heads at the front and a head where his tail would be. In his humanoid form, Nhb-Kaw may hold a serpent in each hand. Nhb-Kaw was frequently found from the end of the $20^{\text {th }}$ Dynasty to the beginning of the $21^{\mathrm{st}}$ among small faience Figures of deities as serpent with human legs and arms ${ }^{(18)}$ raised to the mouth of the deceased ${ }^{(19)}$. The texts differentiated in

$\left({ }^{13}\right)$ R.H.,Wilkinson, The Complete Gods and Goddesses of Ancient Egypt (Cairo, 2003), 125.

$\left({ }^{14}\right)$ K. Sethe, Die Altaegyptische, 1146 b.

$\left({ }^{15}\right)$ E. Hornung, Das Amduat. Die Schrift des Verborgenen Raums, Ägyptologische Abhandlungen 1-7 (Leipzig, 1963), 287.

$\left({ }^{16}\right)$ Rosetau: according to the Underworld Books, it the area known to the ancient Egyptians as Rosetau, the name which given to the Memphite Necropolis that designating the underworld. It the place where identical serpents are found as at the first register of the fourth hour of the Amduat which called "the Path Belonging to Rosetau" (A.Piankoff, \&E.Drioton, The Tomb of Ramesses VI, 255.

$\left({ }^{17}\right)$ "Breath of his Mouth", P. Bucher, Les Textes des Tombes de Thoutmosis III et d'Aménophis II, Mémoires Publiés par les Members de l'Institut Francais d'Archéaologie Orientale 60 (Le Caire, 1932), 25.

$\left({ }^{18}\right)$ E.G. Daressy, Statues, pl.xliii.

$\left({ }^{19}\right)$ This form of Nhb-Kaw also occurs on the thrones of statuette of the goddesses Sakhmet and Bastet (For example see A.W. Shorter, Two 
defining who is his mother and his wife, the Pyramid Texts mentioned in some of its episodes the relation between him and his mother"The King looks at you as Nhb-Kaw when looking at his mother Selket" ${ }^{(20)}$.While the Coffin Texts ${ }^{(21)}$ point out that, Nhb-Kaw was the son of Geb and Renaut "Nhb-Kaw, the Son of Geb who is born from his Mother Renaut".He is also appeared in accompany of other strange serpents resemble those who depicted in the illustrations of the Underworld Books. A wooden Figure in theBritish Museum (No.11779) shows Nhb-Kaw appears with offerings on the Metternich Stela performing the same function ${ }^{(22)}$.

2) He also seen as a man with a serpent's head, kneeling and grasping a serpent in each hand. An example of this form may perhaps be recognized (Fig.5) on one of the ivory wandsin the British Museum (No.18175) ${ }^{(23)}$.

\section{The cult of Nhb-Kaw}

The cult of Nhb-Kaw was practiced at Herakleopolis Magna (modern Ihnasya el- Medina) and probably in other locations. A feast of the god is known to have been celebrated since at least the Middle Kingdom on the first day of the first month of the winter season. The powerful nature of Nhb-Kaw also led to his use in many amuletsand magical spells indicates that he was assumed to exercise a protective function for the living individual as well ${ }^{(24)}$.

The relationship between Nhb-Kaw and other serpent-deities

- The connection of Nhb-Kaw with goddesses Sakhmet and Bastet and other serpent-demons appears in the reminiscence of the original character of those as enemies of the sun-god. It is known from various passages in the religious texts that the cat and the lynx (an animal of cat-like nature) were

Statuettes of the Goddess Sakhmet-Ubastet, Journal of Egyptian Archeology 18 (Cairo, 1932), 121-124.

$\left({ }^{20}\right)$ M. Lurker, The Gods and Symbols of Ancient Egypt, Thames and Hudson (London, 1980), 106; R.O. Faulkner, The Ancient Egyptian Pyramid Texts, Translated into English\&Supplement of Hieroglyphic Texts (Atlanta, 1969), 96 note.4.

$\left({ }^{21}\right)$ A. De Buck, The Egyptian Coffin Texts 4 (Chicago, 1935-1961), 392 hi.

$\left({ }^{22}\right)$ V.S. Golénischeff, Die Metternichstele, Wissenshaftliche Buchgeselischaft Darmstadt (Leipzig, 1877), pl.v, No.xxi.

$\left({ }^{23}\right)$ A.W. Shorter, The God Nḥ b-Kaw, Journal of Egyptian Archeaology 21 (Cairo, 1935), 41-48.

$\left({ }^{24}\right)$ R.H. Wilkinson, The Complete Gods, 225. 
the sworn foes of these serpent-demons. In Pyr.438 (spell no.17), the serpents in-di.f and dsr-ip are destroyed by the lynx (m3fdt) ${ }^{(25)}$; in Book of the Dead spell 17, line.22, the vignette shows the serpent Apophis being slaughtered by the "male cat of $\mathrm{Ra}^{(26)}$. The papyrus of Ankhefen-khonsu ${ }^{(27)}$, a funerary work of the Late New Kingdom, refers to Sakhmet as a slayer of Apophis.

Sakhmet here acts in her capacity as the Eye of Ra, and it is probably as much that she is conceived as the vanquisher of Nhb-Kaw and the other serpentsrepresented on the sides of her throne ${ }^{(28)}$.

In addition number of texts in which it does not at once appear clear what deity is meant by the title Nhb-Kaw:

- Pyr.Texts, 1146. The deceased king is identified with Nhb-Kaw. The parallel versions given by Sethe and Pepi: He is Nhb-Kaw of numerous coils. Merenrea: Merenreais a serpent (hfaw) of numerous coils.

- Pyr.Texts, 229. This passage occurs in a spell directed against serpents which are hostile to the dead.O you are of Atum which is upon the vertebra of Nhb-Kaw, which brings to an end the strife in Hermopolis, fall! Perish $^{(29)}$ !

- Book of Am Duat ${ }^{(30)}$, Fourth Division, the sun-god says:Beholds, I pass the Impassable Place, I pass to greet Osiris. O Nhb-Kaw in your

$\left({ }^{25}\right)$ See also Book of the Dead, Spell 149, sect.7, in which the serpent Rerek is killed by the lynex.

$\left.{ }^{(26}\right)$ Similar scenes appear even earlier on the magical ivory wands (W. Petrie, Objects of Daily Use, British School of Archaeology in Egypt (London, 1927), pls.xxxvi, No.7; xxvii, h (B.M. 24425), k (B.M.9135).

$\left({ }^{27}\right)$ Enkhefenkhons was a "god's father" (it nt r) of Amon Ra the sonand an "engraver of the Haus of Amun"; his father Amenope is among other things entitled "Opener of the Doors of Heaven in Karnak", a titled often borne by the High priest of the Theban Amun. Thetitles of Enkhefenkhons and of his father indicate that the papyrus comes from the Theban Necropolis. The greater part of the papyrus is occupied by a series of representations such as are found in copies of the "Book of him who is in the Tei" (R.V. Lanzone, Domicile des Esprits, Papyrus du Musee de Turin, the Glencairn Museum Archives (Paris, 1879), pls.40-45).

$\left({ }^{28}\right)$ M.A. Blackman, The Funerary Papyrus of 'Enkhefenkhons', Journal of Egyptian Archeology 4 (Cairo, 1817), 122-129.

$\left({ }^{29}\right)$ H. Kees, Der Götter glaube im Alten Aegypten (Leipzig, 1941), 55.

$\left({ }^{30}\right)$ H.Frankfort, The Cenotaph of Seti I at Abydos II, Vol.39, Egypt Exploration Society, (London, 1933), pl. xl, 1, 12. 


\section{The Serpent God Nhb-Kaw}

cavern, with lifted (?) head, great one, serpent fierce of look, behold, I pass the Impassable Place, I pass to greet Osiris.

- (b) dsr-tp, "Splendid (or, holy) of Head", appears in Pyr.Texts, 401, where, together with other beings, he assists the deceased king to obtain his meal off the slaughtered gods: It is dsr-tp who watches them for Teti, and drives them to him.

In 438 dsr-tp occurs together with in-di.fas serpents dangerous to the deceased, who is destroyed by the lynx (m3fdt):Recitation: The lynx springs upon the neck of in-di.f, she returns to (or,attacks again) the neck of dsr$\operatorname{tp}^{(31)}$.

The Relation between Nhb-Kaw and the sun god Ra

There are a number of texts which mention Nhb-Kaw where it is possible to understand the name as an epithet of the sun-god ${ }^{(32)}$. The most important are as follows:

a) Pyr.339:They (the gods) till the beautiful name of this Wenis to Ra, they announce this Wenis to Nhb-Kaw.

b) Pyr.355, 360:They (the gods) tell the beautiful name of Pepy to Ra, they proclaim the beautiful name of Pepy to Nhb-Kaw.

c) Book of the Dead, spell 30 (Theban):Homage unto you, you gods with tresses of hair, adorned with your scepters! Tell you my excellence (or, beauty) to Ra, hand me over to Nhb-Kaw! He, the (deceased) shall land in the west.

d) Book of the Dead, Spell 17, sect.25:The deceased says: I fly as a hawk, I have cackled as a goose, I destroy eternity like Nhb-Kaw ${ }^{(33)}$.

e) Book of the Dead, Spell 15:Addressing the sun god: You sail over the sky in life and well-being, Nhb-Kaw ${ }^{(34)}$ being in the Maandt-boat. The boat rejoices, and your heart is glad, the two uraei shining on the prow. The daily boat has been linked with the sun god as he (Ra) was similar to Nhb-

$\left({ }^{31}\right)$ A.W. Shorter, The God Nhb-Kaw, 43.

$\left({ }^{32}\right) \mathrm{H}$. Grapow, Religiöse Urkunden. Ausgewählte Texte des Totenbuches, Urkunden des Ägyptischen Altertums, Band.V, (Berlin, 1916), 27; E. Naville, Das Aegyptische Totenbuch der XVIII bis XX Dynastie (Berlin, 1886), pl. Cxxxv.

$\left({ }^{33}\right)$ H.Grapow, Religiöse, 63.

$\left({ }^{34}\right)$ It might, however, be contended that the name, with Ka in singular and serpent determinative, is a miswriting for a mere epithet nhb-kaw, and that it should be translated "O Appointer of Positions in Maandit boat", or also, "in life and well-being, O Nhb-Kaw, in the Maandit-boat", the sun god being meant in both cases. 
Kaw in order to pass the daily hours of the western horizon, in addition the most important part from the boat ismade out from the bones of Nhb-Kaw' backbone ${ }^{(35)}$.

While the Book of the Dead mentions that Ra would pass the horizon as: "Neheb-Kaw in the daily boat of Mmdt, your boat and heartwould rejoice while the justice on your forehead" ${ }^{(36)}$.

Only one passage mentions Nhb-Kaw as an enemy, wherehe is attacked by the sun-god Atum. The existence of this evil role, however, is also demonstrated by this inclusion among the many ${ }^{42}$ fearsome deities $^{(37)}$ and demons who make up the forty-two assessors of the tribunal of Osiris. But, like other ferocious deities, he could be placated and won over as a friend, and it is mainly in this aspect that he appears in Egyptian religious texts. In the Pyramid Texts he would seem to have become a powerfuldeity and no doubt sinister associate of the sun-god himself, whose good offices are solicited on behalf of the deceased king, that he may announce the latter's name and rank to $\mathrm{Ra}$, who will then receive him into his kingdom. In one passage the king even goes so far as to identify himself with Nhb- Kaw ${ }^{(38)}$.

In the last-mentioned capacity which reminded of the great serpent Mehen $^{(39)}$ (also not a uraeus) who protected the sun-god during his nightly voyage through the Underworld ${ }^{(40)}$.

While there are some forms or determinatives of serpents that belonged to Rain: the form of Atum:

The form of single uraeus

$\left({ }^{35}\right)$ A. De Buck, The Egyptian Coffin Texts 5 (Chicago,1961) 143 a; R.O. Faulkner, The Ancient Egyptian Coffin Texts 2 (Warminster,1978), note 45.

$\left({ }^{36}\right)$ E. Naville, Das Aegyptische Totenbuch der XVIII bis XX Dynastie (Berlin,1886), 15 a.

$\left({ }^{37}\right)$ The serpent $\mathrm{d} s \mathrm{sr}-\mathrm{tp}$, who in Pyr 438 is evidently considered to be an enemy, but who in 402 assists the king to slaughter the gods for his meal.

$\left.{ }^{38}\right)$ A.W. Shorter, The God Nhb-Kaw, 46.

$\left({ }^{39}\right)$ K. Mysliwiec, Studien zum Gott Atum I, Hildesheimer Ägyptologische Beiträge 1 (Germany, 1987), 104, note.48; A. Gardiner, The Library of A.Chester Beatty Description of a Hieratic Papyrus 7 (Oxford,1931) 1.9, 2.7 .

$\left({ }^{40}\right)$ H. Kees, Der Götterglaube im Alten Aegypten, (Leipzig,1941), 55; A.

De Buck, The Egyptian Coffin Texts 2 (Chicago, 1935-1961), 51-54. 


\section{The Serpent God Nhb-Kaw}

Atum said that:"I am the southern wall, I am the ruler of the God, I am the King of Heaven, while Nhb-Kaw is the Ruler of the two Lands, NhbKaw the giver of Soul" ${ }^{(41)}$.

The form of single uraeus with two raiseheads

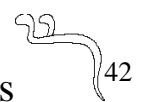

The form of uraeus with two legs, it is a kind of reptiles which related to god Atum in the Pyramid Texts ${ }^{(43)}$.

Festivals of Nhb-Kaw ${ }^{(44)}$

\section{1- The New Year Festival}

a) A matter which remains unexplained connection, if any, between Nhb-Kaw as a demon serpent deity and the New Year festival of that name, Pieper ${ }^{(45)}$ suggests that New Year's Day, the symbol of the eternal recurrence of the year, was associated with Nhb-Kaw, who himself stood for eternity, and he recalls the phrase "I destroy eternity like Nhb-Kaw ${ }^{(46)}$.

b) Nhb-Kaw was revered at a place calledsppt ${ }^{(47)}$. Gauthier ${ }^{(48)}$ suggests that this should be understood as "La Ville du Sistre", and that it is perhaps to be identified the ancient Egyptian name of the Seventh Nome of Upper Egypt. There was also a temple of Nhb-Kaw in connection with the temple of the Greek ram-headed god Harsaphes at Herakleopolis Magna (Fig.6) ${ }^{(49)}$.

$\left({ }^{41}\right)$ A.De Buck, The Egyptian Coffin Texts 6 (Chicago, 1935-1961), 268 (sp.647).

(42)A.De Buck, The Egyptian Coffin Texts 5, 143 (sp.389).

$\left({ }^{43}\right) \mathrm{K}$. Sethe, Übersetzung und Kommentarzu den Altägyptischem Pyramiden texten II, (Hamburg, 1936), 229; É. Drioton, Textes Religieux de Tomb eaux Saites, American Society of Association Excutives 52, (Washington, 1952), 108.

$\left({ }^{44}\right)$ H. Kees, Göttinger to Enbuch stüdiene in Mythus von Konigtum des Osiris in Herakleopolis aus dem Totenbuch, Zeitschrift für Ägyptische Sprache und Altertumskunde 65, (Wiesbaden, 1930), 65-83.

$\left({ }^{45}\right)$ M. Pieper, Die GrooseInschrift des Königs Neferhotep in Abydos, Mitteilungen der Vorderasiatisch-Aegyptischen Gesellschaft 32- 2 (Leipzig, 1929), 41.

$\left({ }^{46}\right)$ M.A. Blackman, The Funerary Papyrus, 122-129.

$\left({ }^{47}\right)$ A. Mariette, Abydos: Description des Fouilles Exécutées sur l'Emplacement de Cette Ville I (Paris, 1880), 44.

$\left({ }^{48}\right) \mathrm{H}$. Gauthier, Dictionnaire des Noms Géographiquescontenus dans les Textes Hiéroglyphiques 5 (Le Caire, 1925), 65.

$\left({ }^{49}\right)$ Of the Twenty-Sixth Dynasty. published by P. Pierret, Recueil d'Inscriptions Inédits du Musée Égyptien du Louvre, I partie, Études 
c) The following references to Nhb-Kaw in the Chester Beatty papyri, just published, are of interest

1) Chester Beatty VIII B. Nhb-Kaw is invoked, among other deities, for the protection of the dwelling-house. He is apparently intended to prevent serpents from entering through a hole in the wall or floor.

2) Chester Beatty VIII ${ }^{(50)}$. In this fragmentary text a tantalizing reference to theserpents is found, which inter to the interior of Nhb Kaw (with curious spelling

3) Chester Beatty VIII A. in a series of invocations to Ra-Horakhte the god is hailed as Nhb-Kaw.

4) Chester Beatty VIII A. Nhb-Kaw appears in association with Ra, in a spell for protecting various parts of the human body by identification with those of divinities.

d) In the vignette of Assessors accompanying the negative confession in the papyrus of Ani ${ }^{(51)}$, Neheb-Kaw, dsr-tp ${ }^{c}$ nd nhp-nfrt are all represented as having the heads of serpents. That eventually Nhb-Kaw confusion with the uraeus is shown by the corresponding vignette in the papyrus of Anhai ${ }^{(52)}$ where Nhb-Kaw, in-c- f,dsr-tp and Nhp-nfrt are all represented actually as uraei ${ }^{(53)}$.

e) When describing the statuette of Sakhmet-Bastet which is seen at JEA 18 (Fig.7), we should overlook Cairo No.38924. This is the lower

Égyptologiques 8, (Paris,1879), 15-16. See also H. Brugsch, Religion und Mythologie der Alten Aegypter, Wissenshaftliche Buch Geselischaft Darmstadt (Leipzig, 1883), 305.

$\left({ }^{50}\right)$ A.H. Gardiner, Egyptian Hieratic Texts III. Literary Texts of the New Kingdom I. The Papyrus Anastasi I and the Papyrus Koller, together with the parallel texts (Leipzig, 1911), 71.

$\left.{ }^{51}\right)$ A. Ernest, The Book of the Dead: Fascimile of the Papyrus of Ani in the Britisch Museum (London, 1894), 32.

$\left.{ }^{52}\right)$ The Papyrus of Anhai was found at El Deir el-Bahri and it was purchased, along with several objects which formed part of the funeral furniture of the deceased. It is valuable rather as a work of art than as an authority for the text of any portion of the Book of the Dead (A.Ernest, The Book of the Dead: Facsimiles of the Papyri of Hunefer, Anhai, Kerasher and Netchemet. with Supplementary Text from the Papyrus of $\mathrm{Nu}$, (London, 1899), 71).

$\left({ }^{53}\right)$ E.G. Daressy, Statues Des Divinities, (Cat, Gen, du Musee du Caire (La Caire, 1905-1906), pl.xlvi. 
portion of a seated statuette of Mut-Sakhmet-Bastet, and the array of divine Figures on the side of her throne. Also the representation of Naples ${ }^{(54)}$ of Sakhmet grasping a serpent with a head at each end.

\section{2- Wepet-Renpet:}

Ancient Egyptians celebrated the New Year with a festival called Wepet Renpet, or "opening of the year". The Egyptian New Year was not celebrated on an exact date because it corresponded with the Nile River's annual flooding as it is ensured the fertility of the farmlands for the following year which was celebrated with feasts and communitygatherings. It dates back to the Middle Kingdom, it is related with "the Kaw" ${ }^{(55)}$ or the food:

Tb iprtsw in nhb-Kaw.

"The First Day of the Winter, the First Day of Nhb-Kaw". It is called "Festival of Nhb-Kaw" and also "the Beginning of Eternity", occurred in day 1, mentioned at the festivals' list of Amun-Ra at El-Karnak temple, the reign of Thutmosis III hrw n wb-rnpt hbhb-Kaw hb hr wtb i rnpt prt sddt.

"The First Day of year, Festival of Nhb-Kaw, Festival of the Beginning of year, the Appearance of Sobed Star".

Kitchen points out that this event of wb-rnpt was significant at the Old Kingdom to the New Year, at the Middle Kingdom signifies to the festival of Nhb-Kaw at the first day of winter season; while at the New kingdom. While sometimes, it was occurred at the first day of year, tpi-rnpt and continued to the Greek Roman period ${ }^{(56)}$

Schott mentioned that Nhb-Kaw Festival was the coronations' day of the king at the Ramesside Period ${ }^{(57)}$.Parker ${ }^{(58)}$ says that it is paralleled to the Sed festival of king Ramesses II, and the Coronation Day of king Ramesses III at Madinet Habu "Beginning of Winter; First Day; the Exit of Nhb-Kaw;

$\left.{ }^{54}\right)$ R.V .Lazone, Domicile des Esprits, Papyrus du Musee de Turin, the Glencairn Museum Archives (Paris, 1879), Fig.4.

$\left({ }^{55}\right)$ A.Erman, Wörterbuch der Aegyptischen Sprache Akademie-Verlag, ed. H.Grapow, (Berlin, 1926-1961), 91 a.

$\left.{ }^{56}\right)$ K. Kitchen, Festkalender, Lexikon der Ägyptologie 2 (Wiesbaden,1977), 191-192; R. Parker, Calendar of Ancient Egypt", Studies in Ancient Oriental Civilization, Vol.26, Chicago, 1950), 36.

$\left({ }^{57}\right)$ S. Schott, Altägyptische Fest daten: Abhandlungen des Geistes- und Sozialwissenschaftlichen Klasse 10, (Wiesbaden, 1950), 93, 87.

$\left({ }^{58}\right)$ R.Parker, 1950, Calendar of Ancient Egypt, Studies in Ancient Oriental Civilization 26, (Chicago, 1950), 37. 
the Festival of Royalist of Ramesses III"(59).

\section{Conclusion}

In ancient Egyptian culture, the special powers of the serpent drive fromthe same divine substance as that of the fiery sun eye Nhb-kaw in Egyptian terminology was originally the explanation of thecause of binding of $\mathrm{Ka}$ and $\mathrm{Ba}$ after death. Thus his name, whichmeans (one who) brings together Ka. Since these aspects of the soul weresaid to bind after death, he was said to have guarded the entrance to Duat.

Itwas one of the most important glyphs in his name, and although it was technically a variation on the glyph for two arms raised in prayer, it also resembles a two-headed serpent, and so Nhb-Kaw became depicted in art as a serpent with two heads (occasionally with only one).

As a two- headed serpent, he was viewed as fierce, being able to attack from two directions, and not having to fear as much confrontations. Consequently sometimes it was said that Atum, the chief god in these areas, had to keep his finger on him to prevent Nhb-Kaw from getting out of control. Alternatively, in areas where Ra was the chief god, it was said that Nhb- Kaw was one of the warriors who protected Ra whilst he was in the underworld, during Ra's nightly travel, as a sun god, under the earth.

When he was seen as a serpent, he was also thought to have some power over serpent-bites, and by extension, other poisonous bites, such as those of scorpions, thus sometimes being identified as the son of Serket, the scorpion-goddess of protection against these things.

${ }^{(59)}$ J. Breasted, Madinet Habu 3 (Chicago, 1956), 163. 


\section{Figures}

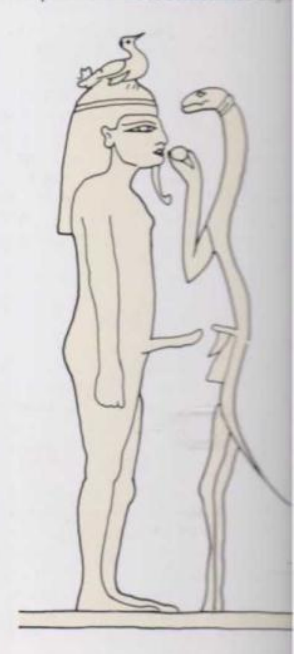

Fig 1. The protective and assistive deity Nhb-Kaw, in the form of serpentman, feeds the deceased, Detail of a cartonnage mummy case, Louvre, Paris.

After, R.H. Wilkinson, The Complete Gods, 224.

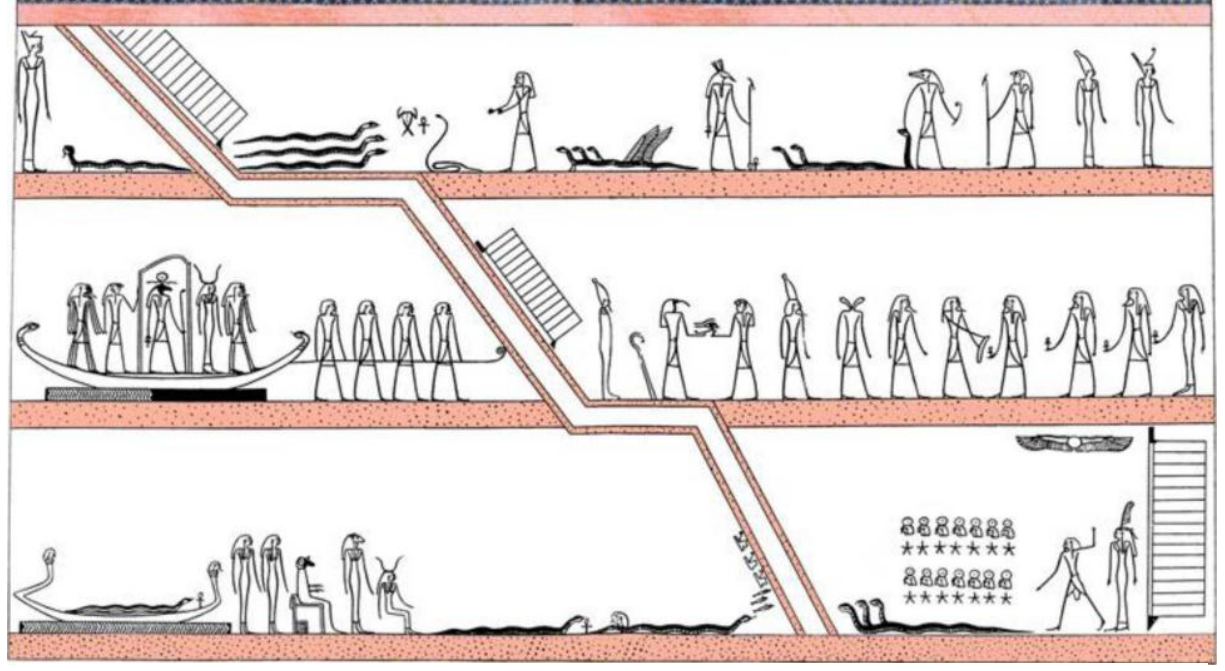

Fig.2, First register of the fourth hour where Nhb-Kaw as the one "with numerous coils" with two heads on separate necks.

After, E.Hornung, The Ancient Egyptian Books of the Afterlife (United States of America, 1997), 352. 


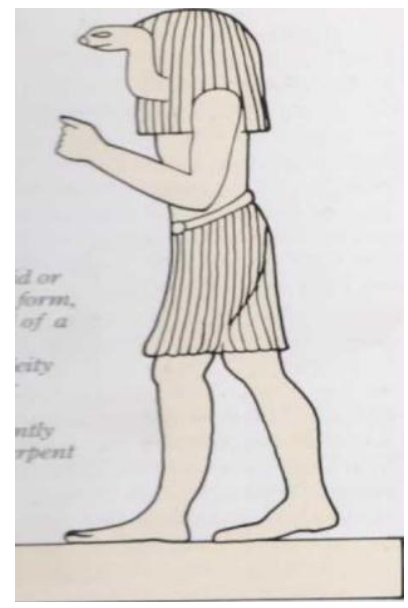

Fig.3,Nhb-Kaw in hybrid or semi-anthropomorphic form, as a man with the head of a serpent. This type of representation of the deity tends to appear in later contexts

After, R.H.Wilkinson, The Complete Gods, 225).

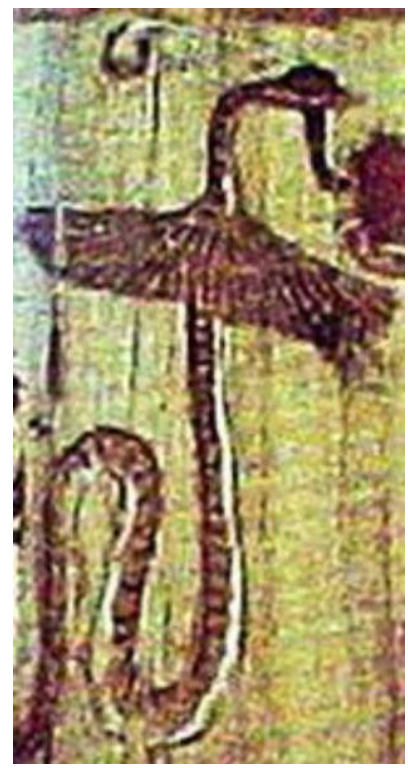

Fig.4, Nhb-Kaw in the form of a winged serpent After, A.W. Shorter ,The God Nhb-Kaw, 41-48). 


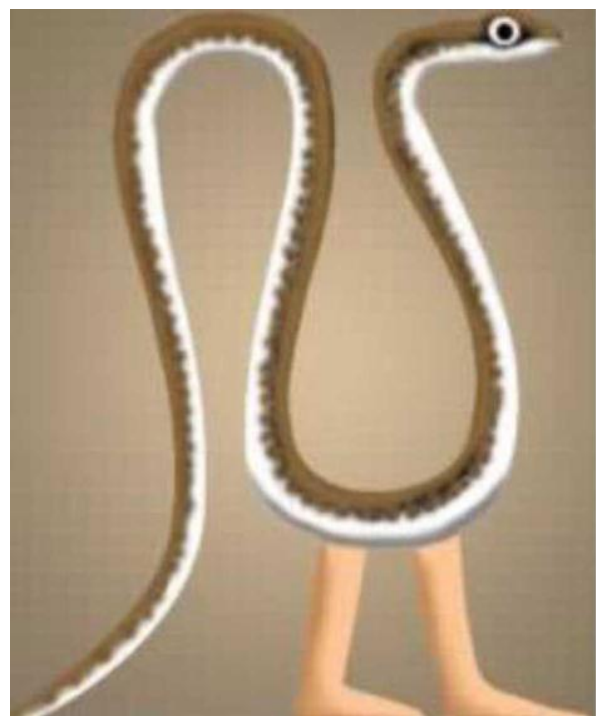

Fig.5,Nhb-Kaw as a coiled serpent with human legs .

After, N.B. Hansen, Snakes, Oxford Encyclopedia of Ancient Egypt 3 (New York, 1999), 296-298.

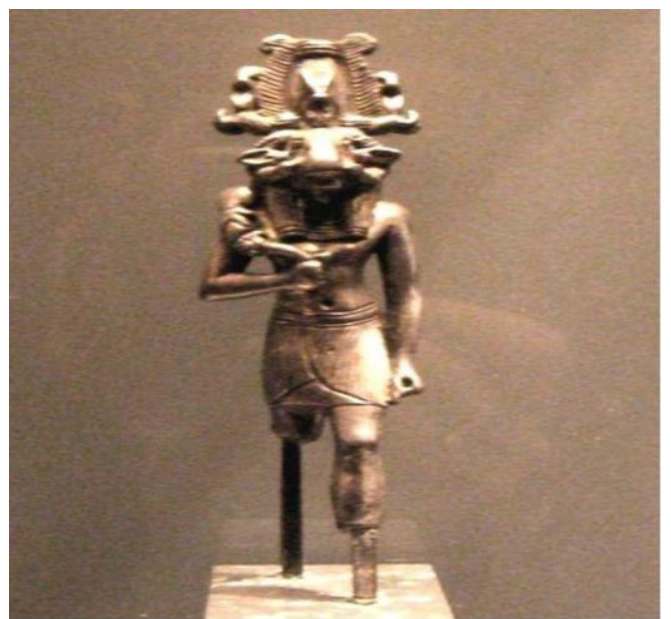

Fig.7,The Greek ram-headed god Harsaphes at Herakleopolis Magna, the Egyptian Heri-shef.

After, W. Hambly, The Serpent in a Africa Belief and Custom, American Anthropologist 31 (Chicago, 1929), 655. 


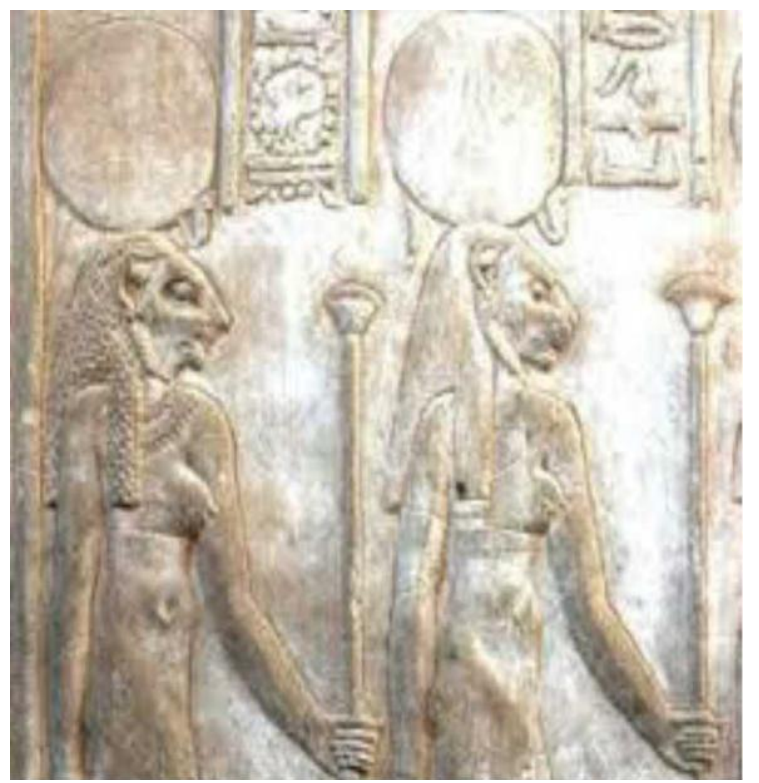

Fig.8, The statuette of Bastet and Sakhmet as a serpentine-goddesses After, E. Otto, Bastet, Lexikon der Agyptologie 1, (Wiesbaden, 1972), 628630. 


\section{References}

- Altenmüller, B., Synkretismus in den Sargtexten, (German, 1975).

- Barta, W., Nehebkau, Lexicon der Ägyptologie, Band 6 (Wiesbaden, 1982), 388-390.

- Blackman, M.A., The Funerary Papyrus of 'Enkhefenkhons, Journal of Egyptian Archeology 4, (Cairo, 1917), 122-129.

- Breasted, J., Madinet Habu 3 (Chicago, 1956).

- Brugsch, H., Religion und Mythologie der Alten Aegypter (Leipzig, 1883).

- Bucher, P., Les Textes des Tombes de Thoutmosis III et d'Aménophis II, Mémoires Publiés par les members de l'institut Francais d'archéaologie Orientale 60, (Le Caire, 1932).

- Daressy, E.G., Statues Des Divinities, (Cat, Gen, du Musee du Caire, (La Caire, 1905-1906).

- De Buck, A., The Egyptian Coffin Texts 4 (Chicago, 1935-1936).

- Drioton, É., Textes Religieux de Tomb eaux Saites, American Society of Association Excutives 52,(Washington, 1952).

- Erman, A., Grapow, H., (ed.,), Wörterbuch der Aegyptischen Sprache Akademie-Verlag, Band 4 (1926-1961,Berlin).

- Ernest, A., The Book of the Dead: Fascimile of the Papyrus of Ani in the Britisch Museum (London, 1894).

------, The Book of the Dead: Facsimiles of the Papyri of Hunefer, Anhai, Kerasher and Netchemet. with Supplementary Text from the Papyrus of $\mathrm{Nu}$ (London, 1899). 1933).

- Frankfort, H., The Cenotaph of Seti I at Abydos II 39 (London,

- Faulkner, R.O., The Ancient Egyptian Pyramid Texts, Translated into English\&Supplement of Hieroglyphic Texts (Atlanta, 1969).

- -----, The Ancient Egyptian Coffin Texts 7 (Warminster, 1987).

- Gardiner, A., Egyptian Hieratic Texts III.Literary Texts of the New Kingdom I. The Papyrus Anastasi I and the Papyrus Koller, together with the parallel texts, (Leipzig, 1911).

- Gardiner, A., The Library of A.Chester Beatty. Description of a Hieratic Papyrus 7 (Oxford, 1931).

- Gauthier, H., Dictionnaire des Noms Géographiques Contenus dans les Textes Hiéroglyphiques 5 (le Caire, 1925).

- Grapow, H., Religiöse Urkunden.Ausgewählte Texte des Totenbuches, Urkunden des Ägyptischen Altertums 5 (Berlin, 1916).

- Hambly, W., The Serpent in Africa Belief and Custom, American Anthropologist 31 (Chicago, 1929). 
- Hansen, N.B., Snakes, Oxford Encyclopedia of Ancient Egypt 3 (New York, 1999).

- Hornung, E., Das Amduat. Die Schrift des Verborgenen Raums, Ägyptologische Abhandlungen 1-7 (Leipzig, 1936).

- ----, The Ancient Egyptian Books of the Afterlife (United States of America, 1999).

- Kees, H., Göttinger to Enbuch Stüdienein Mythus von Konigtum des Osiris in Herakleopolis aus dem Totenbuch, Zeitschrift für Ägyptische Sprache und Altertumskunde 65 (Wiesbaden, 1930).

- ----, Der Götter glaube im Alten Aegypten (Leipzig,1941).

- Kitchen, K., Festkalender, Lexikon der Ägyptologie 2 (Wiesbaden, 1977).

- Lanzone, R.V., Domicile des Esprits, Papyrus du Musee de Turin, the Glencairn Museum Archives (Paris, 1879).

- Leitz, Ch., Lexikon der Ägyptischen Götter und Götterbezeichnungen 6 (Germany, 2002). 1980).

- Lurker, M., The Gods and Symbols of Ancient Egypt (London,

- Mariette, A., Abydos: Description des Fouilles Exécutées sur l'emplacement de cette Ville I (Paris, 1880).

- Müller, M.W., The Mythology of all Races (Boston, 1918).

- Mysliwiec, K., Studien zum Gott Atum I, Hildesheimer Ägyptologische Beitra $\square$ ge, Vol.1, (German, 1987).

- Naville, E., Das Aegyptische Totenbuch der XVIII bis XX Dynastie, (Berlin, 1886).

- Otto, E., Bastet, In W. Helck; et al. Lexicon der Agyptologie, 1 (Wiesbaden, 1972).

- Parker, R.A., Calendar of Ancient Egypt, Studies in Ancient Oriental Civilization 26 (Chicago,1950).

- Petrie, W., Objects of Daily Use, British School of Archaeology in Egypt (London, 1927).

- Pierret, P., Recueil d'Inscriptions Inedits du Musee Egyptien du Louvre, $\mathrm{I}^{\mathrm{re}}$ partie, Etudes Egyptologiques 8 (Paris, 1897), 15-16. 1954).

- Piankoff, A., \&Drioton, E., The Tomb of Ramesses VI (New York,

- Pieper, M., Die GrooseInschrift des Königs Neferhotep in Abydos, Mitteilungen der Vorderasiatisch-Aegyptischen Gesellschaft 32-2 (Leizig, 1929).

- Sethe, K., Die Altaegyptische Pyramidentexte: nach den Papierabdrücken und Photographien des Berliner Museums (Leipzig, 
1922).

----, Übersetzung und Kommentarzu den Altägyptischem Pyramidentexten 2 (Hamburg, 1936).

-----,Dramatische Texte zu Altaegyptischen Mysterienspielen, Untersuchungenzur Geschichte und Altertumskunde Ägyptens 10 (Hildesheim, 1964).

- Shorter, A.W., Two Statuettes of the Goddess Sakhmet-Ubastet, Journal of Egyptian Archeology 18 (Cairo, 1932), 121-124.

- The God Nhb-Kaw, Journal of Egyptian Archeaology 21 (Cairo, 1935), 41-48.

- Speleers, L., 1924, Les Textes des Pyramides Égyptiennes, Revue des Études Anciennes 2 (Bruxelles, 1924), 54-58.

- Wilkinson, R.H., The Complete Gods and Goddesses of Ancient Egypt (Cairo, 2003). 


\section{الملخص العربي}

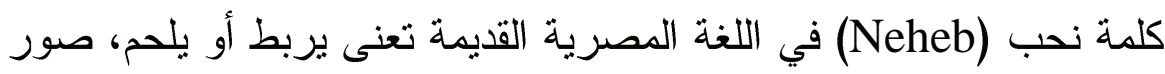

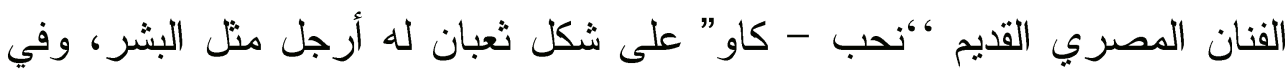

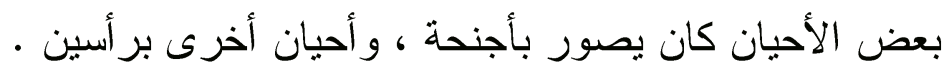

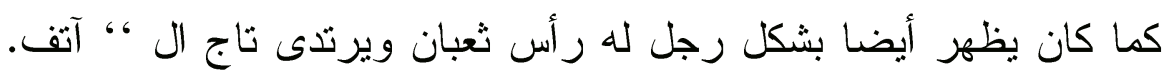
وجاء ذكر ثعبان أل “نحب - كاو” في منون الأهرام (في هرم الملك وذنى ونس)،

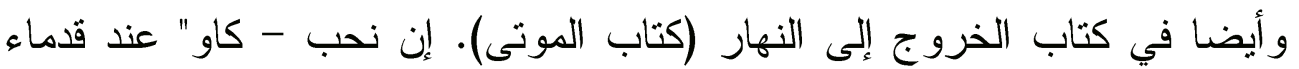

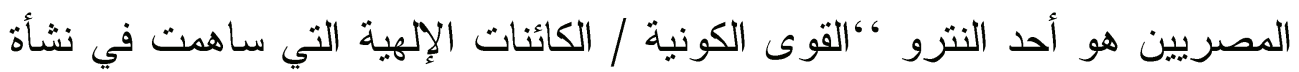

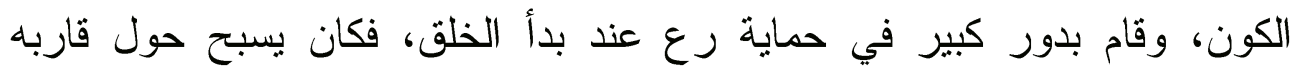

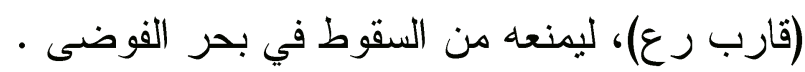

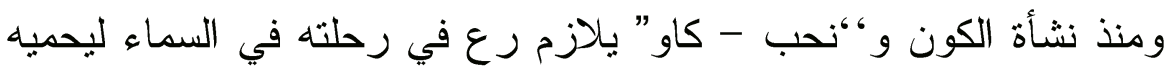

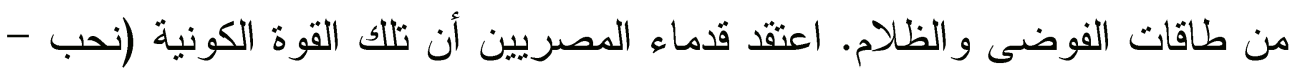

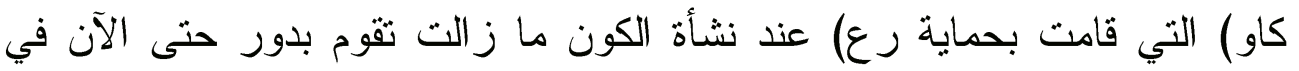

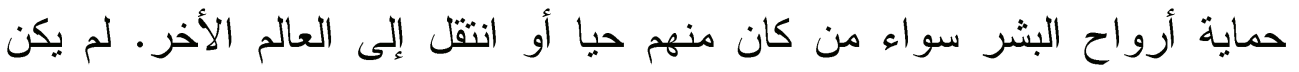
“نحب - كاو ” يحمي الأرواح فقط بل كان أيضا طاقة شافية ، فكان يشفي بشكل

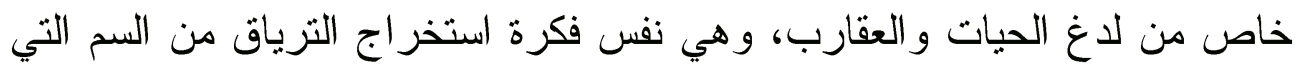
ظهرت فيما بعد ذلك كرمز للطب الحديث حيث نرى شعار الطب الحية السامة، و هو رمز لإمكانية تحول السم إلى ترياق شافي كان نحب - كاو " هو أحد الكائنات

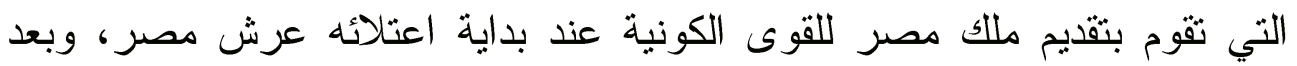
انتقال الملك إلى العالم الآخر يقوم “نب - كاو” بحماية روح الملك (وكذلك أرواح

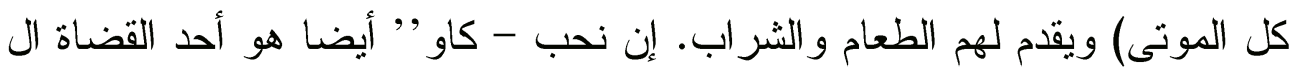
ب9 الذين يقومون بالإشر افعلى محاكمة الأرواح في قاعة الكام الماعت (العدل / النظام

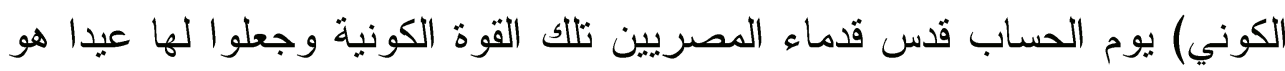
عيد ال نحب - كاو، الذي كان يقام في الثهر الخامس من السنة (شهر طوبة)،

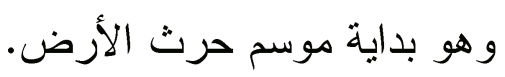

